\title{
EFFECT OF DIFFERENT CONCENTRATION OF POMEGRANATE PEEL AND SEED EXTRACT ON SOME CHEMICAL, PHYSICAL TRAITS AND SENSORY EVALUATION OF KARADY SHEEP MEAT DURING DIFFERENT FROZEN STORAGE
}

\author{
ALAN TOFEIK GHARIB ${ }^{1}$ and AYAD BAKER MAHMMOD ${ }^{2}$ \\ ${ }^{1}$ G.D. of Agriculture in Sulaimani, Ministry of Agriculture and Water Resources, Sulaymaniyah, Iraq. \\ ${ }^{2}$ Animal Sciences, College of Agricultural Engineering Sciences, University of Sulaimani, Iraq.
}

Received: 18 December 2019; Accepted: 9 January 2020

\begin{abstract}
The experiment carried out to examine the effect of pomegranate peel extract (PPE) and pomegranate seed extract (PSE) on some proximate chemical composition (Moisture, Protein, Fat, and Ash), chemical traits (pH value, Thiobarbioteric acid and Free Fate acids), Physical traits (Water holding capacity and $\mathrm{pH}$ ) and sensory evaluation of karady meat during frozen storage period $(0,30,60$ and 90$)$ days at $-18^{\circ} \mathrm{C}$. Meat pieces (Freshly Longissimus dorsi (LD) muscle) were divided into nine treatments: T1consider as control (not immersed with PSE or PPE), T2 (immersed with $0.3 \%$ PSE), T3 (0.6\% PSE), T4 (0.9\% PSE), T5 (1.2\% PSE), T6 (0.3\% PPE), T7 (0.6\% PPE), T8 (0.9\% PPE) and T9 (1.2\% PPE). Meat samples were dipped with PSE and PPE for 24 hours, then stored under frozen condition $\left(-18^{\circ} \mathrm{C}\right)$ for $(0,30,60$ and 90$)$ days. Results indicated that PSE lead to a significant increase of Protein, Fat, Ash, pH, and over all acceptability also PSE lead to a significant decrease of (Moisture, and TBA). On the other hand, PPE lead to Significant increase of (Fat, Ash, TBA, FFA, WHC, and over all acceptability). PPE lead to a significant decrease of (Moisture, Protein, pH and Juiciness). The karadi sheep meat exhibited higher $(\mathrm{P}<0.05)$ Flavor and aroma, Tenderness and Juiciness in meat of T4 (PSE $0.9 \%)$ compared with T1. and recorded higher Color and over all acceptability at T3 (PSE 0.6\%) compared withT1. different freezing storage (0,30, 60 and 90) days showed higher percentage of (Protein, Fat, Ash, FFA and pH).
\end{abstract}

Keywords: Pomegranate Seed, Pomegranate peel, Chemical composition, chemical traits, Physical traits and sensory evaluation.

\section{INTRODUCTION}

Meat and meat products provide the majority of the nutrients required for human health. Meat is recognized as a significant source of high biological value protein and micronutrients (including for example vitamins B6, B12, E and iron) and certain minerals which are essential for growth and health of human (Williamson et al., 2005). Sheep meat proves to be an excellent source of high biological value protein, vitamins B-complex, minerals such as iron, copper, zinc and phosphorus, also a source of a long chane omega-3 polyunsaturated fatty acids, which are needed for good health throughout life (Lawire, 2002).

Numerous food products require protection against microbial spoilage during their shelf life. The growing demand of consumers for safe and natural products has resulted in thorough investigations from food authorities and researchers to assess the feasibility of mild preservation techniques and to

Corresponding author: Dr. ALAN TOFEIK GHARIB E-mail address: alan_dabagh@yahoo.com

Present address: G.D. of Agriculture in Sulaimani, Ministry of Agriculture and Water Resources, Sulaymaniyah, Iraq improve the microbial quality and safety of products, with maintaining their good nutritional and organoleptic properties (Burt, 2004). The use of synthetic antioxidants in food has been decreased due to their suspected action as promoters of carcinogenesis, as well for the general consumer rejection of synthetic food additives (Namiki, 1990). In the recent years, there has been a huge demand for natural antioxidants mainly because of adverse toxicological reports on many synthetic compounds. These natural antioxidants have been extracted from different plant parts like Leaves, roots, stems, fruits, seeds and bark. The application of plant extracts as antioxidants have been studied extensively in different types of meat and meat products. These studies show promising results regarding the use of plant extracts as antioxidants in meat (Shah et al., 2014). The pomegranate is one of the important dietary sources of antioxidant phenolics (Ozgen et al., 2008). Pomegranate peel is recognized for antimicrobial activity (Braga et al., 2005), anticancer property (Jeune et al., 2005.), antiatherosclerotic and antioxidative capacities (Tzulker et al., 2007). Pomegranate (Punica granatum L.) is better known in some countries as the fruit of Eden (Al-Quran) for its pleasant taste and excellent health benefiting 
properties. Therefore, in the view of the above considerations, the present study designed to investigate the effect of different concentrations of pomegranates peels and seeds extract and different freezing storage periods on some physiochemical and sensory properties changes on Longissimus dorsi muscle (LD ) in karadi sheep during frozen storage at $-18^{\circ} \mathrm{C}$ for $(0,30,60,90)$ days.

\section{MATERIALS AND METHODS}

\section{1- Preparation of samples}

Longissimus dorsi muscle (LD) w separated from male karadi sheep carcasses which slaughtered at about 12-14 months age, and storage at $4^{\circ} \mathrm{C}$ for 24 hour. Shelf connective tissues and external fat removed from $\mathrm{LD}$, then the (LD) muscle were slit into approximately $3 \times 3 \mathrm{~cm}$ slices.

\section{2- Expermintal treatments:}

Freshly harvested, ripened and mature pomegranate fruits local species (Sallaxhani) were purchased from Sazan village near Hallabja, Iraq (Season October 2018). The pomegranate transported to higher education laboratory, department of Animal science, college of Agriculture engineering scienceUniversity of Sulaimania. Were the present experiment was carried out.

\section{3- Preparation of pomegranate Peel powder:}

Pomegranate fruits were washed by distilled water then cut manually to separate the arils and peel and their edible portions were carefully separated, the pomegranate peel was cut to small pieces about $2 \times$ $2 \mathrm{~cm}$ by using a sharp Knife and washed by distilled water then dried in air, after $24 \mathrm{~h}$ the peels dried in a ventilated oven at $40^{\circ} \mathrm{C}$ for $48 \mathrm{~h}$. Dried pieces were powdered in heavy duty kitchen grinder and ground to a fine powder and passed through a 24 mesh sieve and stored in refrigerator at $4^{\circ} \mathrm{C}$.

\section{4- Preparation of pomegranate seed powder:}

Pomegranate seed were washed by distilled water then the pomegranate arils shall be pressed manually to extract pomegranate juice. The seed crust was removed by hand carefully so as not cause harm or broken the pomegranate seeds, then the seeds was washed by distilled water and dried in air after $24 \mathrm{~h}$ the seeds dried in a ventilated oven at $40^{\circ} \mathrm{C}$ for $48 \mathrm{~h}$. Dried seeds were powdered in heavy duty kitchen grinder and grounded to a fine powder and passed through a 24 mesh sieve and stored in refrigerator at $4^{\circ} \mathrm{C}$.

\section{5- Preparation of Pomegranate peels and seed extraction:}

$150 \mathrm{~g}$ powdered sample of Pomegranate peel and seed were extracted with 3 liter of distilled Water the mixture was keep it on magnetic stirrer at room temperature for $48 \mathrm{~h}$, and then filtered through cheese cloth to removal of peel particles. The combined filtrate was concentrated in a ventilated oven at $40^{\circ} \mathrm{C}$ for $48 \mathrm{~h}$. The extract was dried and stored in refrigerator at $4^{\circ} \mathrm{C}$ until use meat pieces (Freshly Longissimus dorsi (LD) muscle) were divided to nine treatments: T1consedred as control (not immersed with PSE or PPE), T2 (immersed with $0.3 \%$ PSE), T3(immersed with $0.6 \%$ PSE), T4 (immersed with $0.9 \%$ PSE), T5 (immersed with 1.2\%PSE), T6 (immersed with $0.3 \%$ PPE), T7 (immersed with $0.6 \%$ PPE), T8 (immersed with $0.9 \%$ PPE) and T9 (immersed with 1.2\% PPE). All treated sample was stored in freezing storage at $-18 c^{\circ}$ for $(0,30,60$ and 90) day.

\section{6- Analyses and measurement 6-1- Proximate chemical composition}

\section{6-1-1- Moisture percentage}

Moisture content was determined according to AOAC (2000) by drying $5 \mathrm{gm}$ of meat in oven at $105^{\circ} \mathrm{C}$ until constant weight obtained, then the weight differences was calculated and moisture percent was determined.

\section{6-1-2- Protein percentage}

Total Nitrogen is measured according to the standard AOAC (2000) procedures by using (micro- kjeldahl) procedure and conversion factor of 6.25 to extract protein percent in meat sample used.

\section{6-1-3-Fat Percentage}

The percentage of fat in muscle (LD) is measured by using Soxhlet extraction units where hexane is used as a solvent according to a AOAC (2000) procedures.

\section{6-1-4- Ash percentage}

Procedures of AOAC (2000) were used for Ash determination. $5 \mathrm{gm}$ of meat was put in silica dish then transferred to a muffle furnace maintained at $525^{\circ} \mathrm{C}$ for $16-18 \mathrm{hr}$ till grey ash was obtained then left to be cooled, then it weighed and Ash percent was calculated according to:

$$
\text { Ash } \%=\frac{\text { Ashweight }}{\text { Sampleweightbeforeashing }} \times 100
$$

\section{6-2- Chemical traits}

\section{6-2-1-Thiobarbuteric acid}

Determine of TBA was measured according to the method described by Witte et al. (1970). $20 \mathrm{~g}$ of minced meat were blended with $50 \mathrm{ml}$ of cold solution containing 20\% (Trichloroacetic acids (TCA) in $2 \mathrm{ml}$ Phosphoric acid) the resulting slurry was then transferred in to a $100 \mathrm{ml}$ with distilled water, the homogenized by Shaking and filtered through Whatman no. 1 filter paper. $(5 \mathrm{ml})$ of filtrate solution was pipette into test tube and added $5 \mathrm{ml}$ of fresh chilled Thiobarbituric acid $(0.005 \mathrm{M}$ in distilled water). The test tube was shaken well and placed in the dark room at temperature $\left(25^{\circ} \mathrm{C}\right)$ for $15-17 \mathrm{hr}$ for change the color of solution and developing the 
reaction color. Spectrophotometer (Shimdzu, Japan) was used and the absorbance was read at $530 \mathrm{~nm}$ to calculate the TBA value. The TBA value was expressed as mg MDA/ $\mathrm{Kg}$ meat, which it was calculated by multiplying the absorbance by 5.2 factors as following:

$\mathrm{TBA}(\mathrm{mg} \mathrm{MDA} / \mathrm{Kg}$ meat $)=\mathrm{A} \times 5.2$

\section{6-2-2- Free fatty acid:}

Free fatty acids (FFA) were determined according to the method described by Egan et al. (1981). Ten gram of meat was dissolved in the neutral solvent chloroform and filtered through whatman No.1 filter paper. The filtered was titrated with $0.1 \mathrm{~N}$ of sodium hydroxide $(\mathrm{NaOH})$, with shaking constantly until a pink color appeared. The FFA was calculated as follows:

FFA $\%=\frac{0.282 \times m l N A O H(0.1 N)}{\text { WeightofSample }(g)} \times 100$.

\section{6-3- Physical test}

\section{6-3-1- Water holding capacity:}

According to Wardlaw et al. (1973) procedure water holding capacity was determined for meat sample. Twenty gram of minced meat was mixed with $30 \mathrm{ml}$ of Nacl $(0.6 \mathrm{M})$ in centrifuge tube and mixed for $1 \mathrm{~min}$. the sample was placed into refrigerator at $5^{\circ} \mathrm{c}$ for $15 \mathrm{~min}$. then centrifuged at $\left(4^{\circ} \mathrm{C}\right)$ for $5000 \mathrm{rpm}$ for $25 \mathrm{~min}$. the supernatant was decanted and measured. WHC was reported as $\mathrm{ml}$ of $0.6 \mathrm{M} \mathrm{Nacl}$ per $100 \mathrm{~g}$ of muscle as following:

$\mathrm{WHC} \%=$

$\frac{\text { Initial Solutionwieght-final Solutionweight }}{\text { sampleweight }(\mathrm{g})} \times 100$.

\section{6-3-2- pH Value Determination}

$\mathrm{pH}$ value of meat was determinate according to the determination method described by Ibrahim et al. (2011). $10 \mathrm{~g}$ of meat sample was homogenized in $100 \mathrm{ml}$ of distilled water for $1 \mathrm{~min}$ in a blender and the $\mathrm{pH}$ was measured using a digital $\mathrm{pH}$ - meter (WTW. Multi 350i, India).

\section{6-4- Sensory Evaluation}

Sensory evaluation of samples was carried out by nine member panels from Animal sciences dept of agriculture engineering sciences / University of Sulaimani. And all were experienced in sensory evaluation of meat and meat production. Panelist members were using quantitative descriptive analysis methods for different attributes color, flavor and aroma, tenderness, juiciness and over all acceptability with five point scales ranging between 1 and 5 . The description of sensory properties and how to rate a sample for the particular sensory property were on the evaluation form. The sample were dry cooked in an oven at $165^{\circ} \mathrm{C}$ for $10 \mathrm{~min}$ until reaching the internal temperature of $70^{\circ} \mathrm{C}$ then cooled to $60^{\circ} \mathrm{c}$ prior to test.
(Murphy and Zerby, 2004). Approximately a (20gm) of meat sample were served on plates to panelists and a glass of water at room temperature was provided to each assessor between samples. The panel scores were as (Table 1).

\section{Statistical analysis}

Statistical Package for the Social Science (SPSS, 2018) was used for all data in this experiment were analyzed to Evaluate the effect of two different factor (Treatment and period) by factorial analysis in a Completely Randomized Design (CRD). Duncan (1955) multiple range tests were used to detect a significant difference among means for each factors without interaction between the factors. Assuming the following statistical model:

1- Effect of treatment in study parameters:

$y i j=\mu+T i+e i j$

2- Effect of period in study parameters:

$y i j=\mu+p i+e i j$

Where:

$y i j=$ Observational value of sample

$\mu=$ Overall mean

$T i=$ Effect of $\mathrm{i}_{\text {th }}$ treatment (pomegranate Peels: 0.3, $0.6,0.9$, and $1.2 \%$. or Pomegranate Seed: 0.3, 0.6, 0.9 , and $1.2 \%$ ).

$p i=$ The Effect of Period (0, 30, 60 and 90 days).

$e i j=$ Random error associated with each observation assumed to be NID with Zero mean and $\sigma^{2}$ e variance.

\section{RESULTS}

\section{1- Effect of Pomegranate Peel and Seed extract on Karadi sheep meat Moisture during different freezing storage $(0,30,60$, and 90$)$ days:}

Result presented in table (2) that there were a significant $(\mathrm{P}<0.05)$ decrease moisture content recorded for all treatments except T3 $(80.58 \%)$ which treated by 0.6 PSE (pomegranate Seed extraction) at (0) day storage period compared with T1 (80.04\%). moisture percentage was significantly decreased as a result of the different PSE and PPE treat after 30 day frozen storage. In table (2), there is no significant difference $(\mathrm{P}>0.05)$ between the means of Moisture during (60) day freezing storage. PSE showed decrease of moisture percentage as compared with control T1 $(75.59 \%)$. Also decreases of moisture percentage were observed for all treatment except $\mathrm{T} 1$ at (30) days frozen (81.74\%) which record highest moisture percentage as compared with control and other treatments (table 2). PPE at T7 recorded lower Moisture content as compared with other treatments during (90) days frozen. 


\section{2- Effect of Pomegranate Peel and Seed extract on} Karadi sheep meat Protein during different frozen storage $(0,30,60$, and 90$)$ days:

Rise of protein percentage observed significantly $(\mathrm{P}<0.05)$ for all means at $(0)$ day storage period (Table 3). The protein content in control was $(14.80 \%)$ at (0) day. highest increase was recorded by T5 $(16.33 \%)$, and T6 (16.95\%) recorded higher protein percentage for PPE. During 30 day of frozen storage significantly differences $(\mathrm{P}<0.05)$ observed in Protein percentage after treating different PSE and PPE while compared with T1 (14.64). Result in Table (3) showed significant effect $(\mathrm{P}<0.05)$ of the PSE and PPE on the protein value, When we compare the effect of the treatments with control we found that all protein means increased significantly except T2 (14.18) showed decrease of protein value during (30) days frozen storage. Significant differences $(P<0.05)$ between the means of protein content during 60 days frozen storage (Table 3) were recorded. Protein value increased significantly in all treatments as compared with T1 (15.26).

\section{3- Effect of Pomegranate Peel and Seed extract on Karadi sheep meat Fat during different freezing storage $(0,30,60$, and 90$)$ days:}

Significant differences $(\mathrm{P}<0.05)$ observed among the means of Fat (table 4) at (0) day storage period and fat content gradually increased. The highest content of fat recorded in T1 (3.02\%) control during (90) days frozen storage and T9 $(3.01 \%)$ as compared with the lower fat content was T1 control $(1.2 \%)$. The fat content was increased significantly during (30) day frozen storage. Table (4) results clarified that there is a significant differences among the means of fat content during (60) days frozen storage, Gradually Fat content increased in all treatments as compared with T1 (1.83\%). Whereas, the highest fat content were recorded in T9 $(3.00 \%)$ during (60) days frozen.

\section{4- Effect of Pomegranate Peel and Seed extract on Karadi sheep meat Ash during different freezing storage $(0,30,60$, and 90$)$ days:}

Result in table (5) showed that there is no significant difference $(\mathrm{P}>0.05)$ among means of Ash at $(0)$ day frozen storage, the highest Ash percentage was found at T5 PSE (1.92\%) and T6 PPE (1.92\%). Significant differences $(\mathrm{P}<0.05)$ between the means of Ash after treated by PSE and PPE different concentration during (30) day frozen storage (table 4). The highest Ash content was at T2 (2.36\%) during (90) days frozen and the lower ash content was T1 $(0.94 \%)$ at (0) day frozen. It was noticed in table (5) results that no significant differences $(\mathrm{P}>0.05)$ were observed between the means of Ash during (60) days frozen storage and Lower Ash content recorded by $\mathrm{T} 7$
$(2.12 \%)$ and higher Ash content was recorded in T5 $(2.28 \%)$ as compared with control.

\section{5- Effect of Pomegranate Peel and Seed extract on Karadi sheep meat TBA during different freezing storage $(0,30,60$, and 90$)$ days:}

Significant differences $(\mathrm{P}<0.05)$ was found between the means of TBA at $(0)$ day storage, result showed that T3 $(0.58 \mathrm{mg} / \mathrm{MDA} / \mathrm{kg})$ differ significantly among T1 and T2, T4 and T5 of PSE. On the other hand (Table 6) showed that during (0) day frozen the highest value recorded in T9 $(0.63 \mathrm{mg} / \mathrm{MDA} / \mathrm{Kg})$ among all treatments except T1 $(0.68 \mathrm{mg} / \mathrm{MDA} / \mathrm{Kg})$ control while the lowest value recorded in T4 (0.46) malonaldehyde/ $\mathrm{kg}$. In present study table (6) showed significant differences $(\mathrm{P}<0.05)$ between treatment during (30) days frozen storage. the initial TBA value of the control T1 was (0.35)mg/MDA $/ \mathrm{kg}$ after (30) days frozen storage, TBA value of control was higher significantly than all treatments except $\mathrm{T} 9$ which record highest TBA value $(0.36 \mathrm{mg})$ and $\mathrm{T} 3$ was lower TBA value $(0.13 \mathrm{mg})$. The result in table (6) show that there is a significant differences $(\mathrm{P}<0.05)$ among the means of TBA value in karady sheep meat treated by different concentration of PSE and PPE during (60) days frozen storage. All treatments showed decrease in TBA value as compared with control T1 (0.53mg MDA/Kg) during (60) days frozen. As a result the lower TBA value was recorded by $\mathrm{T} 7(0.08 \mathrm{mg} / \mathrm{MDA} / \mathrm{Kg})$ during (90) days frozen and the higher TBA value was recorded by $\mathrm{T} 1$ $(0.68 \mathrm{mg} / \mathrm{MDA} / \mathrm{Kg})$ during (0) day frozen.

\section{6- Effect of Pomegranate Peel and Seed extract on Karadi sheep meat FFA value during different freezing storage $(0,30,60$, and 90$)$ days:}

Table (7) results showed significant effect $(\mathrm{P}<0.05)$ of FFA during (0) day storage, when making compartment among treatments at the same periods we found that FFA percentage rise gradually compared to control T1 $(0.21 \%)$ and the highest value recorded in T5 $(0.30 \%)$ for PSE. And for PPE the highest record was T9 $(0.36 \%)$ which it was a highest records for all treatments during $(0)$ day frozen. There was a significant difference $(\mathrm{P}<0.05)$ among means of treatments. The table (7) showed the effect of PSE and PPE on FFA. Rise of FFA content observed as compared with control in present study during (30) days frozen storage, $\mathrm{T} 8$ recorded the highest value of FFA content $(0.35 \%)$ and $\mathrm{T} 1$ control was the lower FFA content $(0.27 \%)$. Results in table (7) showed significant differences $(\mathrm{P}<0.05)$ among the treatments, differ in FFA content were observed in meat during 60 days frozen storage, both PSE and PPE recorded gradually increase in FFA content. The higher FFA content was T8 $(0.44 \%)$ at (90) days frozen and lower FFA content was T1 control $(0.26 \%)$ 


\section{7- Effect of Pomegranate Peel and Seed extract on} Karadi sheep meat pH during different freezing storage $(0,30,60$, and 90$)$ days:

Significant differences showed between the means of $\mathrm{pH}$ value of meat treated by PSE and PPE at (0) day storage. Generally decrease of $\mathrm{pH}$ value was observed in all treatment after treated by different percentage of PSE and PPE at some storage day. T8 and T9 recorded significantly lower $\mathrm{pH}$ (4.97) compared with all treatment except T1. On the other hand, highest $\mathrm{pH}$ value was observed in T2 (5.21) compared with all treatments at (0) day frozen. Table (8) results indicated that no significant differences observed in $\mathrm{pH}$ value during 30 day frozen storage. PPE led to decrease of $\mathrm{pH}$ value, T5 (5.08) recorded lower $\mathrm{pH}$ value compared with T1 (5.29) control and T2 (5.38) recorded highest $\mathrm{pH}$ value compared with control. Results in table (8) significant differences $(\mathrm{P}<0.05)$ was observed between the means of $\mathrm{pH}$ value in meat which treated with different concentration of PSE and PPE. $\mathrm{pH}$ value of $\mathrm{T} 1$ control was (5.30) after 60 days frozen storage, all meat sample were treated by PSE recorded decrease in $\mathrm{pH}$ value and $\mathrm{T} 4$ (5.17) was lowest $\mathrm{pH}$ value as compared with all other sample. Nevertheless, differences found in $\mathrm{pH}$ value in meat sample treated by PPE and the higher $\mathrm{pH}$ value was T8 (5.40) during 60 days storage Table (8). Higher $\mathrm{pH}$ value were recorded by $\mathrm{T} 3(5.70)$ at 90 frozen days.

\section{8- Effect of Pomegranate Peel and Seed extract on Karadi sheep meat Water holding capacity during different freezing storage $(0,30,60$, and 90) days:}

The results of water holding capacity (WHC) showed in Table (9). There were a significant differences $(\mathrm{P}<$ $0.05)$ between the means of Water holding capacity at (0) day. WHC decreased in all treatment when compared with T1 (43.93\%), T2 (40.09\%) recorded lower WHC value. There were significant differences $(\mathrm{P}<0.05)$ among treatments in water holding capacity during 30 days frozen storage, T3 (52.60\%) was higher WHC and T5 (38.44\%) was lower WHC value when compared with Control T1 (40.57\%). On the other hand, study resulted significant differences $(\mathrm{P}<0.05)$ among means of WHC during 60 days frozen storage, table (9) results of PSE reported rise of WHC percentage as compared with control T1 (37.02\%). Higher WHC percentage was recorded by T4 $(38.96 \%)$. On the other hand lower WHC percentage was recorded by $\mathrm{T} 7(35.97 \%)$. Lower WHC value was recorded by T3 $(21.20 \%)$ at (90) days frozen (Table 9).

9- The Effect of different frozen storage $(0,30,60$ and 90) days on karadi meat composition treated by different concentration of pomegranate peel and Pomegranate seed extract:

The result in table (10) indicated that there was significant difference $(\mathrm{P}<0.05)$ among the means of moisture Protein, Fat and Ash value during (0, 30, 60 and 90) frozen storage days. The result in table (10) showed that lower moisture content was recorded by T4 (71.38\%) during 90 days frozen, T8 (72.70\%) during 90 days frozen for PSE and T9 $(70.00 \%)$ during 90 days frozen in sample treated with PPE. On the other hands higher moisture content was observed in T2 $(80.74 \%)$ at 30 days frozen, T6 $(80.43 \%)$ for PSE during 30 days frozen and for PPE the higher moisture percentage was $(78.73 \%)$ during (0) day frozen. Nevertheless, the higher moisture for all treatments during $(0,30,60$ and 90$)$ days frozen was $\mathrm{T} 2(80.74 \%)$ at 30 day frozen and lower moisture content for all treatment was $(70.00 \%)$ for PPE during (90) days frozen.

Different protein value were indicated during different frozen storage period higher protein content was recorded by T8 (17.85\%) for PSE during 90 days frozen and lower protein content was recorded by $\mathrm{T} 2$ (14.74\%) during 30 days frozen, generally protein content Increased with increase of frozen period. In spite of that, and as a result of frozen storage same increase of fat content observed with the meat samples which treated by PSE, for instance, at (0) day storage Fat content was $(1.7 \%)$ then increased to $(1.9 \%)$ at 30 days frozen storage and at 60 days storage frozen the fat content was $(2.31 \%)$. Similar increase were noticed in meat samples which treated by PPE during frozen storage period, at (0) day fat content was (1.99\%) after (30) days frozen storage fat content increase to $(2.44 \%)$ and at (60) days frozen storage the fat content was $(2.7 \%)$. The lower Fat content recorded by control at (0) time of frozen $(1.2 \%)$ and higher Fat content was recorded in meat sample which treated by PPE at 90 days frozen storage $(3.15 \%)$. Fat Rise of Ash content observed for all treatments with gradually increase of frozen period. In present study the lower Ash content was $(1.82 \%)$ which recorded by sample treated by PSE at 0 days frozen storage and higher Ash content was $(2.25 \%)$ recorded by meat sample treated with PSE at 90 days frozen storage.

\section{0- Effect of different frozen storage day on TBA and FFA on karadi meat treated by different concentration of pomegranate peel and Pomegranate seed extract: \\ 10-1-TBA:}

Result showed (Table 11) significant differences (P $<0.05)$ among means. TBA value of control at (0) day frozen was $(0.68 \mathrm{mg} \mathrm{MDA} / \mathrm{Kg}$ meat) then at 30 days frozen storage the TBA value decreased to $(0.36 \mathrm{mg}$ $\mathrm{MDA} / \mathrm{Kg}$ meat) and at the 60 days frozen storage the TBA value was decreased to $(0.42 \mathrm{mg}$ MDA/ $\mathrm{Kg}$ meat). In meat sample which treated by PSE the value of TBA was decreased with increase of frozen storage time. At (0) day storage TBA value was $(0.51 \mathrm{mg}$ $\mathrm{MDA} / \mathrm{Kg}$ meat) then decreased to $(0.20 \mathrm{mg} \mathrm{MDA} /$ $\mathrm{Kg}$ meat) after 30 days frozen and at 60 days frozen the TBA value was $(0.42 \mathrm{mg}$ MDA/ Kg meat). Similar 
decrease of result of TBA value was observed with the meat sample that treated with PPE, At (0) day storage the TBA value was $(0.53 \mathrm{mg} \mathrm{MDA} / \mathrm{Kg}$ meat) then decreased to $(0.21 \mathrm{mg} \mathrm{MDA} / \mathrm{Kg}$ meat $)$ at 30 days frozen and at 60 days frozen the TBA value was (0.43mg MDA/ Kg meat) (Table 11).

\section{0-2- FFA}

Table (11) results showed significant differences $(\mathrm{P}<$ 0.05 ) among means of FFA content. FFA content for control at (0) time was $(0.21 \%)$ then after 30 days of frozen the FFA content increased to $(0.30 \%)$ with increase of frozen time to 60 days the FFA of control was increased to $(0.35 \%)$ and at 90 days frozen the FFA was $0.39 \%$ for control. Gradually increase of FFA content were found in meat that treated with PSE during (0, 30, 60 and 90) days. At (0) day of storage the FFA content was $(0.27 \%)$ then increased to $(0.29 \%)$ after 30 days frozen storage and at 60 days frozen storage rise of FFA content continue to be $(0.30 \%)$ then at (90) days FFA recorded $(0.32 \%)$. Similar result were observed in meat sample that treated with PPE during (0, 30, 60 and 90) days storage frozen. At (0) day storage the FFA content was $(0.31 \%)$ then at 30 days frozen the FFA content increased to $(0.32 \%)$ while at the 60 days storage frozen the FFA content increased to $(0.38 \%)$ and during (90) frozen FFA recorded $(0.41 \%)$.

\section{1-The Effect of different refrigerator storage days $(0,30,60$ and 90$)$ on $\mathrm{pH}$ and Water holding capacity on karadi meat treated by different concentration of PPE and PSE:}

\section{1-1-pH:}

Table (12) showed significant differences $(\mathrm{P}<0.05)$ between the means of $\mathrm{pH}$ during different frozen storage $(0,30,60$ and 90) days. The $\mathrm{pH}$ value affected by different frozen storage days, gradually increase of $\mathrm{pH}$ value recorded with increase of frozen storage days. $\mathrm{pH}$ value of meat sample at (0) storage days for control was (5.06) after (30) days frozen storage the $\mathrm{pH}$ value increased to (5.20), during (60) days frozen storage days $\mathrm{pH}$ value was (5.27) and at (90) days frozen the $\mathrm{pH}$ value was (5.58). Similar increase were recorded for meat samples treated by PSE, during (0) day frozen the $\mathrm{pH}$ value was (5.17) then at (30) days frozen $\mathrm{pH}$ value was increased to (5.28) and after (60) days frozen storage $\mathrm{pH}$ value was (5.22) and at (90) days was (5.60). Obviously increase of $\mathrm{pH}$ value was recorded in meat samples which treated by PSE, at (0) day storage $\mathrm{pH}$ was (5.01) after (30) days frozen the $\mathrm{pH}$ value increased to (5.14), with increase of storage days to (60) days the $\mathrm{pH}$ value increased to (5.31) and during (90) days $\mathrm{pH}$ was $(5,54)$ for PSE. The lower $\mathrm{pH}$ value was (5.01) recorded at (0) days frozen for meat sample which treated by PPE on the other hand the higher $\mathrm{pH}$ value was (5.60) recorded at (90) days frozen in sample which treated by PSE.

\section{1-2- Water Holding Capacity:}

Significant differences ( $p<0.05$ ) between the means of WHC were indicated during $(0,30,60$ and 90) days frozen storage. Reduction of WHC percentage was obtained in the present study as a result of different storage period Table (12). The WHC percentage in meat sample not treated (control) during (0) day was (43.93\%) after (30) days frozen WHC decreased to $(40.70 \%)$ and at (60) days frozen storage WHC value decreased to $(37.23 \%)$ but during (90) days frozen the WHC percentage was (42.89\%). meat samples which treated by PSE showed difference value of WHC as a result of different frozen storage period for instance, at (0)days storage WHC value was $(41.87 \%)$ but at 30 days frozen the WHC percentage increased to $(46.66 \%)$ and at 60 days frozen the WHC percentage decreased to $(37.90 \%)$ then at (90) days frozen WHC percentage was $(27.73 \%)$. on the other hands, gradually decrease of WHC value were observed in meat sample which treated by PPE as a result of difference frozen storage period, at (0) days storage the WHC percentage was $(42.06 \%)$ then frozen storage increased to 30 days and WHC value was decreased to $(39.09 \%)$ decrease of WHC continue to record $(37.32 \%)$ at 60 days frozen storage and during (90) days frozen storage WHC percentage was $(38.52 \%)$. Table (12) showed that lower WHC percentage was $(27.73 \%)$ recorded by meat sample treated PSE at 90 days frozen, on the other hands the higher WHC was $(46.66 \%)$ recorded by meat sample treated by PSE at (30) days frozen.

12- Effect of different concentration of pomegranate peel and Pomegranate seed extract on Color, Flavor and Aroma, Tenderness, Juiciness and overall acceptability in LD Muscle of Karadi meat during 90 day frozen storage:

Table (13) showed significant differences $(\mathrm{P}<0.05)$ among means treatments of Flavor and Aroma, tenderness, juiciness and over all acceptances. Also table (13) showed that there is no significant differences among the means of color at (60) day storage. PSE T3 (0.6) recorded the highest score (3.80) for color, (4.00) and (3.80) for overall acceptance. On the other hands, T4 recorded higher Flavor and Aroma (4.00) and higher score for Tenderness (4.00).

In spite of that results in table (13) indicated that T4 was more acceptable in Flavor and Aroma which had significantly $(\mathrm{P}<0.05)$ higher score (4.00) as compared with T1 (2.60). Also the table showed that pomegranate seed extraction led to significant $(\mathrm{P}<$ 0.05) decrease in T4 (3.40) as compared with T1. 
Table 1: panel scores Table was as following:

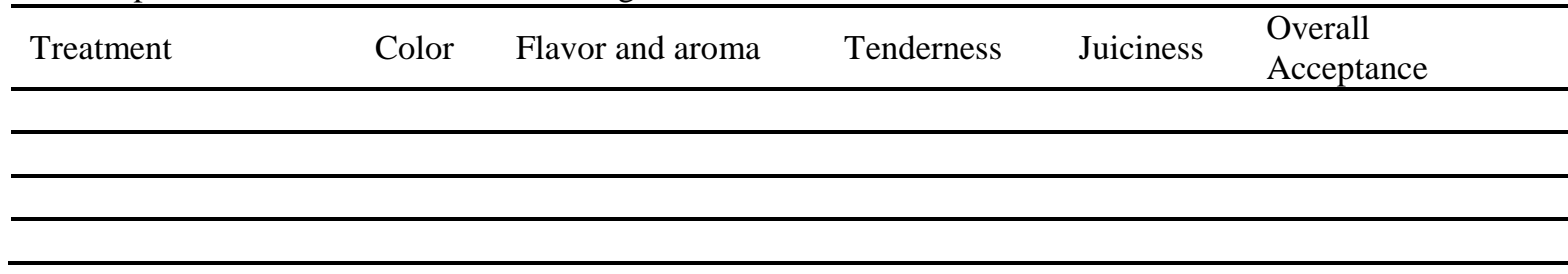

Table 1: Sensory evaluation form (Murphy and Zerby, 2004).

\begin{tabular}{cccccc}
\hline Score & 1 & 2 & 3 & 4 & 5 \\
\hline Color & Very dark & $\begin{array}{c}\text { Dark } \\
\text { brown }\end{array}$ & $\begin{array}{c}\text { Acceptable } \\
\text { brown }\end{array}$ & $\begin{array}{c}\text { Light } \\
\text { reddish brown }\end{array}$ & $\begin{array}{c}\text { Reddish } \\
\text { Brown }\end{array}$ \\
\hline Flavor and aroma & $\begin{array}{c}\text { Very pronounced } \\
\text { rancid }\end{array}$ & $\begin{array}{c}\text { Pronounced } \\
\text { rancid }\end{array}$ & $\begin{array}{c}\text { Moderate } \\
\text { rancid }\end{array}$ & Slight rancid & $\begin{array}{c}\text { No detectable } \\
\text { Rancid }\end{array}$ \\
\hline Tenderness & Tough & $\begin{array}{c}\text { Low } \\
\text { tender }\end{array}$ & $\begin{array}{c}\text { Moderate } \\
\text { tender }\end{array}$ & Tender & Very tender \\
\hline Juiciness & Dry & $\begin{array}{c}\text { Slightly } \\
\text { juicy }\end{array}$ & $\begin{array}{c}\text { Moderate } \\
\text { juicy }\end{array}$ & Juicy & Very juicy \\
\hline Overall acceptance & Refused & $\begin{array}{c}\text { Slightly } \\
\text { acceptable }\end{array}$ & $\begin{array}{c}\text { Moderate } \\
\text { acceptable }\end{array}$ & Acceptable & $\begin{array}{c}\text { Very } \\
\text { Acceptable }\end{array}$ \\
\hline
\end{tabular}

Table 2: Effect of Pomegranate Peel and Seed extract on Karadi sheep meat Moisture percentage during different freezing storage $(0,30,60$, and 90$)$ days (Mean $\pm \mathrm{SE})$ :

\begin{tabular}{|c|c|c|c|c|c|}
\hline \multicolumn{2}{|c|}{$\begin{array}{l}\text { Frozen period } \\
\text { Tre. }\end{array}$} & 0 Day & 30 Day & 60 Day & 90 Day \\
\hline Control & $\mathrm{T} 1$ & $80.04 \pm 0.35^{\mathrm{bc}}$ & $81.74 \pm 0.57^{c}$ & $75.59 \pm 0.26^{\mathrm{a}}$ & $75.08 \pm 0.05^{c}$ \\
\hline \multirow{4}{*}{ PSE } & $\mathrm{T} 2$ & $78.94 \pm 0.38^{b}$ & $80.68 \pm 0.52^{\mathrm{bc}}$ & $74.88 \pm 0.60^{a}$ & $73.21 \pm 0.48^{\mathrm{bc}}$ \\
\hline & $\mathrm{T} 3$ & $80.58 \pm 0.56^{\mathrm{c}}$ & $80.03 \pm 0.56^{\mathrm{abc}}$ & $73.28 \pm 0.07^{\mathrm{a}}$ & $71.87 \pm 0.40^{\mathrm{ab}}$ \\
\hline & $\mathrm{T} 4$ & $79.62 \pm 0.79^{b c}$ & $79.28 \pm 0.60^{\mathrm{abc}}$ & $72.40 \pm 0.25^{\mathrm{a}}$ & $70.67 \pm 0.67^{\mathrm{ab}}$ \\
\hline & $\mathrm{T} 5$ & $78.73 \pm 0.60^{b}$ & $77.45 \pm 0.57^{\mathrm{ab}}$ & $75.35 \pm 2.52^{\mathrm{a}}$ & $70.26 \pm 0.59^{\mathrm{ab}}$ \\
\hline \multirow{4}{*}{ PPE } & T6 & $80.01 \pm 0.20^{\mathrm{bc}}$ & $78.06 \pm 0.66^{\mathrm{ab}}$ & $75.78 \pm 0.49^{a}$ & $70.15 \pm 0.82^{\mathrm{ab}}$ \\
\hline & $\mathrm{T} 7$ & $79.23 \pm 0.21^{\mathrm{bc}}$ & $77.18 \pm 0.17^{\mathrm{a}}$ & $75.57 \pm 0.48^{a}$ & $69.52 \pm 1.01^{a}$ \\
\hline & $\mathrm{T} 8$ & $78.60 \pm 0.43^{b}$ & $79.67 \pm 0.76^{\mathrm{abc}}$ & $75.16 \pm 0.34^{\mathrm{a}}$ & $70.09 \pm 1.05^{\mathrm{ab}}$ \\
\hline & T9 & $77.07 \pm 0.15^{a}$ & $80.74 \pm 1.32^{\mathrm{bc}}$ & $74.57 \pm 0.29^{a}$ & $71.38 \pm 0.65^{\mathrm{ab}}$ \\
\hline
\end{tabular}

Means having different small letters $(\mathrm{a}, \mathrm{b}, \mathrm{c} \ldots)$ among treatments for each Column are significantly different $(\mathrm{P}<0.05)$.

Table 3: Effect of PPE and PSE on Karadi sheep meat Protein percentage during different freezing storage ( 0 , $30,60$, and 90$)$ days $($ Mean $\pm \mathrm{SE})$ :

\begin{tabular}{|c|c|c|c|c|c|}
\hline $\mathrm{Fr}$ & Period & 0 Day & 30 Day & 60 Day & 90 Day \\
\hline Control & $\mathrm{T} 1$ & $14.80 \pm 0.26^{\mathrm{a}}$ & $14.64 \pm 0.30^{\mathrm{ab}}$ & $15.26 \pm 0.27^{\mathrm{a}}$ & $15.91 \pm 0.58^{\mathrm{a}}$ \\
\hline \multirow{4}{*}{ PSE } & $\mathrm{T} 2$ & $14.80 \pm 0.11^{\mathrm{a}}$ & $14.18 \pm 0.35^{\mathrm{a}}$ & $15.60 \pm 0.14^{\mathrm{ab}}$ & $19.00 \pm 1.34$ \\
\hline & T3 & $15.32 \pm 0.32^{\mathrm{a}}$ & $15.99 \pm 0.10^{\mathrm{bc}}$ & $16.14 \pm 0.54^{\mathrm{ab}}$ & $18.18 \pm 0.37^{\circ}$ \\
\hline & $\mathrm{T} 4$ & $15.40 \pm 0.09^{\mathrm{ab}}$ & $16.07 \pm 0.35^{\mathrm{bc}}$ & $15.79 \pm 0.23^{\mathrm{ab}}$ & $18.30 \pm 0.40^{a}$ \\
\hline & $\mathrm{T} 5$ & $16.33 \pm 0.47^{b c}$ & $16.61 \pm 0.09^{c}$ & $17.14 \pm 0.08^{\mathrm{bc}}$ & $18.16 \pm 0.49^{a}$ \\
\hline \multirow{4}{*}{ PPE } & T6 & $16.95 \pm 0.39^{c}$ & $16.05 \pm 0.27^{\mathrm{bc}}$ & $16.59 \pm 0.42^{\mathrm{abc}}$ & $17.33 \pm 0.81^{2}$ \\
\hline & $\mathrm{T} 7$ & $16.59 \pm 0.19^{b c}$ & $16.32 \pm 0.40^{\mathrm{bc}}$ & $17.98 \pm 0.17^{c}$ & $16.08 \pm 0.36^{a}$ \\
\hline & $\mathrm{T} 8$ & $16.06 \pm 0.11^{\mathrm{abc}}$ & $14.66 \pm 0.62^{\mathrm{ab}}$ & $16.15 \pm 0.39^{\mathrm{ab}}$ & $17.26 \pm 0.48$ \\
\hline & T9 & $15.69 \pm 0.48^{\mathrm{abc}}$ & $14.74 \pm 0.34^{\mathrm{ab}}$ & $17.15 \pm 0.47^{\mathrm{bc}}$ & $15.94 \pm 0.52$ \\
\hline
\end{tabular}

Means having different small letters $(\mathrm{a}, \mathrm{b}, \mathrm{c} \ldots)$ among treatments for each Column are significantly different $(\mathrm{P}<0.05)$. 
Table 4: Effect of Pomegranate Peel and Seed extract on Karadi sheep meat Fat percentage during different freezing storage $(0,30,60$, and 90$)$ days (Mean $\pm \mathrm{SE})$ :

\begin{tabular}{|c|c|c|c|c|c|}
\hline 7 & Period & 0 Day & 30 Day & 60 Day & 90 Day \\
\hline Control & $\mathrm{T} 1$ & $1.20 \pm 0.05^{\mathrm{a}}$ & $1.43 \pm 0.08^{a}$ & $1.83 \pm 0.06^{c}$ & $3.02 \pm 0.06^{b}$ \\
\hline \multirow{4}{*}{ PSE } & $\mathrm{T} 2$ & $2.33 \pm 0.03^{\mathrm{e}}$ & $2.43 \pm 0.12^{\text {cd }}$ & $2.35 \pm 0.17^{\mathrm{ab}}$ & $2.90 \pm 0.008^{\mathrm{ab}}$ \\
\hline & T3 & $1.50 \pm 0.15^{b}$ & $1.80 \pm 0.05^{\mathrm{ab}}$ & $2.11 \pm 0.003^{\mathrm{a}}$ & $2.26 \pm 0.003^{a}$ \\
\hline & $\mathrm{T} 4$ & $1.56 \pm 0.03^{b}$ & $1.63 \pm 0.08^{a}$ & $2.26 \pm 0.29^{\mathrm{ab}}$ & $2.93 \pm 0.29^{b}$ \\
\hline & $\mathrm{T} 5$ & $1.50 \pm 0.05^{b}$ & $1.76 \pm 0.08^{a b}$ & $2.53 \pm 0.31^{\mathrm{a}}$ & $2.96 \pm 0.31^{b}$ \\
\hline \multirow{4}{*}{ PPE } & T6 & $1.90 \pm 0.05^{\mathrm{cd}}$ & $2.16 \pm 0.06^{\mathrm{bc}}$ & $2.84 \pm 0.06^{\mathrm{bc}}$ & $3.01 \pm 0.06^{b}$ \\
\hline & $\mathrm{T} 7$ & $2.26 \pm 0.03^{\mathrm{e}}$ & $2.46 \pm 0.06^{\mathrm{cd}}$ & $2.70 \pm 0.12^{a}$ & $2.99 \pm 0.32^{b}$ \\
\hline & $\mathrm{T} 8$ & $2.13 \pm 0.03^{\mathrm{de}}$ & $2.36 \pm 0.14^{\mathrm{cd}}$ & $2.16 \pm 0.06^{\mathrm{ab}}$ & $2.97 \pm 0.02^{b}$ \\
\hline & T9 & $1.66 \pm 0.03^{b c}$ & $2.76 \pm 0.08^{d}$ & $3.00 \pm 0.10^{\mathrm{bc}}$ & $3.01 \pm 0.08^{b}$ \\
\hline
\end{tabular}

Means having different small letters $(\mathrm{a}, \mathrm{b}, \mathrm{c} \ldots)$ among treatments for each Column are significantly different $(\mathrm{P}<0.05)$.

Table 5: Effect of Pomegranate Peel and Seed extract on Karadi sheep meat Ash percentage during different freezing storage $(0,30,60$, and 90$)$ days $($ Mean $\pm \mathrm{SE})$ :

\begin{tabular}{|c|c|c|c|c|c|}
\hline $\mathrm{Fr}_{\mathrm{T}}^{\mathrm{Fr}}$ & Days & 0 & 30 & 60 & 90 \\
\hline Control & $\mathrm{T} 1$ & $0.94 \pm 0.005^{\mathrm{a}}$ & $1.96 \pm 0.005^{\mathrm{a}}$ & $2.17 \pm 0.06^{\mathrm{a}}$ & $2.24 \pm 0.08^{a}$ \\
\hline \multirow{4}{*}{ PSE } & $\mathrm{T} 2$ & $1.6 \pm 0.15^{\mathrm{a}}$ & $2.25 \pm 0.12^{b}$ & $2.24 \pm 0.13^{\mathrm{a}}$ & $2.36 \pm 0.12^{\mathrm{a}}$ \\
\hline & $\mathrm{T} 3$ & $1.87 \pm 0.04^{b}$ & $2.10 \pm 0.02^{\mathrm{ab}}$ & $2.18 \pm 0.01^{\mathrm{a}}$ & $2.22 \pm 0.09^{a}$ \\
\hline & $\mathrm{T} 4$ & $1.90 \pm 0.06^{b}$ & $2.10 \pm 0.01^{\mathrm{ab}}$ & $2.21 \pm 0.14^{\mathrm{a}}$ & $2.25 \pm 0.07^{\mathrm{a}}$ \\
\hline & $\mathrm{T} 5$ & $1.92 \pm 0.01^{b}$ & $2.10 \pm 0.01^{\mathrm{ab}}$ & $2.28 \pm 0.16^{\mathrm{a}}$ & $2.19 \pm 0.05^{\mathrm{a}}$ \\
\hline \multirow{4}{*}{ PPE } & T6 & $1.92 \pm 0.01^{b}$ & $2.09 \pm 0.02^{\mathrm{ab}}$ & $2.24 \pm 0.12^{\mathrm{a}}$ & $2.19 \pm 0.02^{\mathrm{a}}$ \\
\hline & $\mathrm{T} 7$ & $1.91 \pm 0.005^{b}$ & $2.11 \pm 0.02^{\mathrm{ab}}$ & $2.12 \pm 0.04^{\mathrm{a}}$ & $2.15 \pm 0.05^{a}$ \\
\hline & $\mathrm{T} 8$ & $1.90 \pm 0.08^{b}$ & $2.06 \pm 0.03^{\mathrm{a}}$ & $2.15 \pm 0.02^{\mathrm{a}}$ & $2.20 \pm 0.04^{\mathrm{a}}$ \\
\hline & T9 & $1.90 \pm 0.05^{b}$ & $2.00 \pm 0.05^{\mathrm{a}}$ & $2.19 \pm 0.03^{\mathrm{a}}$ & $2.21 \pm 0.04^{a}$ \\
\hline
\end{tabular}

Means having different small letters $(\mathrm{a}, \mathrm{b}, \mathrm{c} \ldots)$ among treatments for each Column are significantly different $(\mathrm{P}<0.05)$.

Table 6: Effect of Pomegranate Peel and Seed extract on Karadi sheep meat TBA (mg malonaldehyde/kg Muscle) during different freezing storage (0, 30, 60, and 90) days (Mean $\pm \mathrm{SE})$ :

\begin{tabular}{|c|c|c|c|c|c|}
\hline Fre. & & 0 Day & 30 Day & 60 Day & 90 Day \\
\hline Control & $\mathrm{T} 1$ & $0.68 \pm 0.002^{f}$ & $0.35 \pm 0.006^{\mathrm{d}}$ & $0.53 \pm 0.007^{\mathrm{c}}$ & $0.14 \pm 0.002^{b c}$ \\
\hline \multirow{4}{*}{ PSE } & $\mathrm{T} 2$ & $0.51 \pm 0.002^{b c}$ & $0.18 \pm 0.006^{\mathrm{b}}$ & $0.37 \pm 0.006^{\mathrm{a}}$ & $0.12 \pm 0.006^{b}$ \\
\hline & $\mathrm{T} 3$ & $0.58 \pm 0.006^{\mathrm{d}}$ & $0.13 \pm 0.004^{\mathrm{a}}$ & $0.35 \pm 0.01^{\mathrm{a}}$ & $0.13 \pm 0.006^{\mathrm{bc}}$ \\
\hline & $\mathrm{T} 4$ & $0.46 \pm 0.01^{\mathrm{a}}$ & $0.15 \pm 0.006^{\mathrm{ab}}$ & $0.42 \pm 0.002^{b}$ & $0.14 \pm 0.004^{b c}$ \\
\hline & $\mathrm{T} 5$ & $0.48 \pm 0.006^{\mathrm{ab}}$ & $0.24 \pm 0.006^{c}$ & $0.48 \pm 0.006^{\mathrm{c}}$ & $0.14 \pm 0.002^{b c}$ \\
\hline \multirow{4}{*}{ PPE } & T6 & $0.48 \pm 0.002^{\mathrm{ab}}$ & $0.28 \pm 0.006^{\mathrm{d}}$ & $0.44 \pm 0.01^{b c}$ & $0.15 \pm 0.005^{c}$ \\
\hline & $\mathrm{T} 7$ & $0.49 \pm 0.004^{\mathrm{ab}}$ & $0.15 \pm 0.01^{\mathrm{ab}}$ & $0.43 \pm 0.007^{b}$ & $0.08 \pm 0.002^{a}$ \\
\hline & $\mathrm{T} 8$ & $0.54 \pm 0.01^{\mathrm{c}}$ & $0.18 \pm 0.003^{\mathrm{b}}$ & $0.37 \pm 0.01^{\mathrm{a}}$ & $0.09 \pm 0.02^{\mathrm{a}}$ \\
\hline & T9 & $0.63 \pm 0.02^{\mathrm{e}}$ & $0.36 \pm 0.01^{\mathrm{d}}$ & $0.42 \pm 0.003^{b}$ & $0.44 \pm 0.01^{\mathrm{d}}$ \\
\hline
\end{tabular}

Means having different small letters $(\mathrm{a}, \mathrm{b}, \mathrm{c} \ldots)$ among treatments for each Column are significantly different $(\mathrm{P}<0.05)$. 
Table 7: Effect of Pomegranate Peel and Seed extract on Karadi sheep meat FFA value during different freezing storage $(0,30,60$, and 90$)$ days $($ Mean $\pm \mathrm{SE})$ :

\begin{tabular}{|c|c|c|c|c|c|}
\hline Ero & eriod & 0 Day & 30 Day & 60 Day & 90 Day \\
\hline Control & $\mathrm{T} 1$ & $0.21 \pm 0.008^{\mathrm{a}}$ & $0.27 \pm 0.01^{\mathrm{a}}$ & $0.26 \pm 0.01^{\mathrm{a}}$ & $0.28 \pm 0.01^{\mathrm{a}}$ \\
\hline \multirow{4}{*}{ PSE } & $\mathrm{T} 2$ & $0.24 \pm 0.01^{\mathrm{ab}}$ & $0.29 \pm 0.005^{\mathrm{abc}}$ & $0.30 \pm 0.01^{b}$ & $0.33 \pm 0.01^{b}$ \\
\hline & T3 & $0.27 \pm 0.003^{b c}$ & $0.31 \pm 0.02^{\text {abcd }}$ & $0.32 \pm 0.01^{\mathrm{bc}}$ & $0.34 \pm 0.005^{b c}$ \\
\hline & $\mathrm{T} 4$ & $0.27 \pm 0.008^{c}$ & $0.32 \pm 0.008^{\text {bcd }}$ & $0.33 \pm 0.01^{b c}$ & $0.36 \pm 0.01^{\mathrm{c}}$ \\
\hline & T5 & $0.30 \pm 0.008^{\mathrm{cd}}$ & $0.28 \pm 0.01^{\mathrm{ab}}$ & $0.35 \pm 0.01^{\mathrm{cd}}$ & $0.40 \pm 0.005^{\mathrm{d}}$ \\
\hline \multirow{4}{*}{ PPE } & T6 & $0.27 \pm 0.01^{b c}$ & $0.33 \pm 0.003^{\text {bcd }}$ & $0.38 \pm 0.02^{\mathrm{de}}$ & $0.39 \pm 0.005^{\mathrm{c}}$ \\
\hline & $\mathrm{T} 7$ & $0.30 \pm 0.008^{\mathrm{cd}}$ & $0.33 \pm 0.01^{\mathrm{cd}}$ & $0.39 \pm 0.01^{\mathrm{de}}$ & $0.41 \pm 0.01^{\mathrm{d}}$ \\
\hline & $\mathrm{T} 8$ & $0.32 \pm 0.011^{\mathrm{d}}$ & $0.35 \pm 0.01^{\mathrm{d}}$ & $0.40 \pm 0.05^{\mathrm{e}}$ & $0.44 \pm 0.01^{\mathrm{d}}$ \\
\hline & T9 & $0.36 \pm 0.017^{\mathrm{e}}$ & $0.30 \pm 0.01^{\mathrm{abc}}$ & $0.35 \pm 0.05^{\mathrm{cd}}$ & $0.39 \pm 0.03^{d}$ \\
\hline
\end{tabular}

Means having different small letters (a, b, c...) among treatments for each Column are significantly different (P $<0.05)$.

Table 8: Effect of Pomegranate Peel and Seed extract on Karadi sheep meat $\mathrm{pH}$ value during different freezing storage $(0,30,60$, and 90$)$ days (Mean $\pm \mathrm{SE})$ :

\begin{tabular}{|c|c|c|c|c|c|}
\hline $\mathrm{Fr}_{\mathrm{T}}^{\mathrm{Fr}}$ & & 0 & 30 & 60 & 90 \\
\hline Control & $\mathrm{T} 1$ & $4.93 \pm 0.01^{\mathrm{a}}$ & $5.29 \pm 0.02^{\mathrm{ab}}$ & $5.30 \pm 0.05^{\mathrm{abc}}$ & $5.37 \pm 0.05^{\mathrm{a}}$ \\
\hline \multirow{4}{*}{ PSE } & $\mathrm{T} 2$ & $5.21 \pm 0.04^{f}$ & $5.38 \pm 0.02^{b}$ & $5.21 \pm 0.01^{\mathrm{ab}}$ & $5.69 \pm 0.01^{\mathrm{c}}$ \\
\hline & T3 & $5.16 \pm 0.01^{\mathrm{def}}$ & $5.09 \pm 0.02^{a}$ & $5.19 \pm 0.05^{\mathrm{ab}}$ & $5.70 \pm 0.06^{c}$ \\
\hline & $\mathrm{T} 4$ & $5.13 \pm 0.004^{\mathrm{de}}$ & $5.35 \pm 0.05^{\mathrm{ab}}$ & $5.17 \pm 0.04^{\mathrm{a}}$ & $5.62 \pm 0.02^{\mathrm{bc}}$ \\
\hline & T5 & $5.19 \pm 0.015^{\mathrm{ef}}$ & $5.08 \pm 0.04^{a}$ & $5.20 \pm 0.006^{\mathrm{ab}}$ & $5.59 \pm 0.02^{\mathrm{bc}}$ \\
\hline \multirow{4}{*}{ PPE } & T6 & $5.11 \pm 0.013^{\mathrm{cd}}$ & $5.15 \pm 0.02^{\mathrm{ab}}$ & $5.34 \pm 0.007^{\mathrm{bc}}$ & $5.58 \pm 0.01^{b c}$ \\
\hline & $\mathrm{T} 7$ & $5.04 \pm 0.013^{b}$ & $5.11 \pm 0.13^{\mathrm{ab}}$ & $5.31 \pm 0.01^{\mathrm{abc}}$ & $5.50 \pm 0.01^{\mathrm{ab}}$ \\
\hline & $\mathrm{T} 8$ & $4.97 \pm 0.024^{\mathrm{a}}$ & $5.21 \pm 0.05^{\mathrm{ab}}$ & $5.40 \pm 0.03^{c}$ & $5.48 \pm 0.02^{\mathrm{ab}}$ \\
\hline & T9 & $4.97 \pm 0.019^{a}$ & $5.20 \pm 0.03^{\mathrm{ab}}$ & $5.27 \pm 0.03^{\mathrm{abc}}$ & $5.58 \pm 0.06^{b c}$ \\
\hline
\end{tabular}

Means having different small letters $(\mathrm{a}, \mathrm{b}, \mathrm{c} \ldots)$ among treatments for each Column are significantly different $(\mathrm{P}<0.05)$.

Table 9: Effect of Pomegranate Peel and Seed extract on Karadi sheep meat Water holding capacity percentage during different freezing storage $(0,30,60$, and 90$)$ days (Mean $\pm S E)$ :

\begin{tabular}{|c|c|c|c|c|c|}
\hline \multicolumn{2}{|c|}{ Fre. } & 0 & 30 & 60 & 90 \\
\hline Control & $\mathrm{T} 1$ & $43.93 \pm 0.44^{\mathrm{d}}$ & $40.57 \pm 0.49^{\mathrm{a}}$ & $37.02 \pm 0.50^{\mathrm{ab}}$ & $31.52 \pm 0.52^{c}$ \\
\hline \multirow{4}{*}{ PSE } & $\mathrm{T} 2$ & $40.09 \pm 0.28^{a}$ & $41.80 \pm 1.02^{\mathrm{a}}$ & $37.69 \pm 0.61^{\mathrm{ab}}$ & $30.35 \pm 0.58^{\mathrm{bc}}$ \\
\hline & $\mathrm{T} 3$ & $42.19 \pm 0.66^{\mathrm{bc}}$ & $52.60 \pm 0.75^{\mathrm{b}}$ & $37.94 \pm 0.97^{\mathrm{ab}}$ & $21.20 \pm 0.18^{\mathrm{a}}$ \\
\hline & $\mathrm{T} 4$ & $42.43 \pm 0.28^{\mathrm{cd}}$ & $51.68 \pm 1.57^{b}$ & $38.96 \pm 0.28^{b}$ & $27.85 \pm 0.74^{b}$ \\
\hline & T5 & $42.79 \pm 0.14^{\mathrm{cd}}$ & $38.44 \pm 0.66^{\mathrm{a}}$ & $38.86 \pm 0.50^{b}$ & $31.12 \pm 0.41^{\mathrm{c}}$ \\
\hline \multirow{4}{*}{ PPE } & T6 & $40.81 \pm 0.41^{\mathrm{ab}}$ & $38.49 \pm 1.00^{\mathrm{a}}$ & $38.06 \pm 0.50^{\mathrm{ab}}$ & $37.48 \pm 0.79^{d}$ \\
\hline & $\mathrm{T} 7$ & $41.73 \pm 0.47^{b c}$ & $39.68 \pm 0.54^{\mathrm{a}}$ & $35.97 \pm 0.56^{\mathrm{a}}$ & $43.12 \pm 1.09^{\mathrm{e}}$ \\
\hline & $\mathrm{T} 8$ & $42.73 \pm 0.82^{\mathrm{cd}}$ & $39.77 \pm 0.47^{\mathrm{a}}$ & $36.39 \pm 0.55^{\mathrm{ab}}$ & $42.34 \pm 0.87^{\mathrm{e}}$ \\
\hline & T9 & $42.98 \pm 0.30^{\mathrm{cd}}$ & $40.70 \pm 0.68^{\mathrm{a}}$ & $37.23 \pm 0.48^{\mathrm{ab}}$ & $42.89 \pm 0.44^{\mathrm{e}}$ \\
\hline
\end{tabular}

Means having different small letters $(\mathrm{a}, \mathrm{b}, \mathrm{c} \ldots)$ among treatments for each Column are significantly different $(\mathrm{P}<0.05)$. 
Table 10: The Effect of different refrigerator storage (0,30,60 and 90) days on karadi meat Proximate chemical composition treated by different concentration of pomegranate peel and Pomegranate seed extract (Mean $\pm \mathrm{SE}$ ):

\begin{tabular}{cccccc}
\hline Treat & \multicolumn{1}{c}{ Frozen storage day } & Moisture & Protein & Fat & Ash \\
\hline & 0 & $78.94 \pm 0.38^{\mathrm{bc}}$ & $15.69 \pm 0.26^{\mathrm{abc}}$ & $1.2 \pm 0.51^{\mathrm{a}}$ & $1.9 \pm 0.005^{\mathrm{ab}}$ \\
\cline { 2 - 5 } C & 30 & $80.74 \pm 1.32^{\mathrm{d}}$ & $14.74 \pm 0.34^{\mathrm{a}}$ & $1.4 \pm 0.88^{\mathrm{ab}}$ & $1.96 \pm 0.005^{\mathrm{ab}}$ \\
\cline { 2 - 5 } & 60 & $74.57 \pm 0.29^{\mathrm{a}}$ & $17.15 \pm 0.47^{\mathrm{d}}$ & $1.8 \pm 0.06^{\mathrm{c}}$ & $2.17 \pm 0.06^{\mathrm{c}}$ \\
\cline { 2 - 5 } & 90 & $71.38 \pm 0.65^{\mathrm{ab}}$ & $15.94 \pm 0.52^{\mathrm{a}}$ & $2.03 \pm 0.08^{\mathrm{a}}$ & $2.24 \pm 0.08^{\mathrm{a}}$ \\
\cline { 2 - 5 } & 0 & $79.73 \pm 0.32^{\mathrm{bcd}}$ & $15.08 \pm 0.15^{\mathrm{ab}}$ & $1.7 \pm 0.11^{\mathrm{bc}}$ & $1.82 \pm 0.05^{\mathrm{a}}$ \\
\cline { 2 - 5 } PSE & 30 & $80.43 \pm 0.36^{\mathrm{cd}}$ & $15.22 \pm 0.27^{\mathrm{ab}}$ & $1.9 \pm 0.10^{\mathrm{c}}$ & $2.14 \pm 0.03^{\mathrm{c}}$ \\
\cline { 2 - 5 } & 60 & $74.04 \pm 0.40^{\mathrm{a}}$ & $15.70 \pm 0.17^{\mathrm{abc}}$ & $2.31 \pm 0.10^{\mathrm{de}}$ & $2.23 \pm 0.05^{\mathrm{c}}$ \\
\cline { 2 - 5 } & 90 & $72.70 \pm 0.53^{\mathrm{c}}$ & $17.85 \pm 0.48^{\mathrm{c}}$ & $2.96 \pm 0.01^{\mathrm{b}}$ & $2.25 \pm 0.04^{\mathrm{a}}$ \\
\hline & 0 & $78.73 \pm 0.35^{\mathrm{bc}}$ & $16.48 \pm 0.16^{\mathrm{cd}}$ & $1.99 \pm 0.07^{\mathrm{cd}}$ & $1.91 \pm 0.01^{\mathrm{ab}}$ \\
\cline { 2 - 5 } PPE & 30 & $78.09 \pm 0.38^{\mathrm{b}}$ & $15.91 \pm 0.28^{\mathrm{bc}}$ & $2.44 \pm 0.07^{\mathrm{e}}$ & $2.07 \pm 0.01^{\mathrm{bc}}$ \\
\cline { 2 - 5 } & 60 & $75.21 \pm 0.57^{\mathrm{a}}$ & $16.96 \pm 0.24^{\mathrm{d}}$ & $2.7 \pm 0.10^{\mathrm{e}}$ & $2.18 \pm 0.03^{\mathrm{c}}$ \\
\cline { 2 - 5 } & 90 & $70.00 \pm 0.39^{\mathrm{a}}$ & $17.21 \pm 0.32^{\mathrm{ab}}$ & $3.15 \pm 0.1^{\mathrm{b}}$ & $2.19 \pm 0.01^{\mathrm{a}}$ \\
\cline { 2 - 5 } & & 90.05.
\end{tabular}

Means having different small letters $(\mathrm{a}, \mathrm{b}, \mathrm{c} \ldots)$ among treatments for each Column are significantly different $(\mathrm{P}<0.05)$.

Table 11: Effect of different refrigerator storage day on TBA and FFA on karadi meat treated by different concentration of pomegranate peel and Pomegranate seed extract (Mean $\pm \mathrm{SE}$ ):

\begin{tabular}{cccc}
\hline Treatment & \multicolumn{1}{c}{ Frozen storage day } & TBA & FFA \\
\hline & 0 & $0.68 \pm 0.002^{\mathrm{d}}$ & $0.21 \pm 0.008^{\mathrm{a}}$ \\
\cline { 2 - 4 } $\mathrm{C}$ & 30 & $0.36 \pm 0.01^{\mathrm{b}}$ & $0.30 \pm 0.01^{\mathrm{bc}}$ \\
\cline { 2 - 4 } & 60 & $0.42 \pm 0.003^{\mathrm{b}}$ & $0.35 \pm 0.005^{\mathrm{de}}$ \\
\cline { 2 - 4 } & 90 & $0.44 \pm 0.02^{\mathrm{c}}$ & $0.39 \pm 0.003^{\mathrm{b}}$ \\
\cline { 2 - 4 } & 0 & $0.51 \pm 0.01^{\mathrm{c}}$ & $0.27 \pm 0.007^{\mathrm{b}}$ \\
\cline { 2 - 4 } & 30 & $0.20 \pm 0.02^{\mathrm{a}}$ & $0.29 \pm 0.008^{\mathrm{bc}}$ \\
\cline { 2 - 4 } & 60 & $0.42 \pm 0.02^{\mathrm{b}}$ & $0.30 \pm 0.009^{\mathrm{bc}}$ \\
\cline { 2 - 4 } & 90 & $0.13 \pm 0.003^{\mathrm{b}}$ & $0.32 \pm 0.009^{\mathrm{a}}$ \\
\hline & 0 & $0.53 \pm 0.01^{\mathrm{c}}$ & $0.31 \pm 0.01^{\mathrm{cd}}$ \\
\cline { 2 - 4 } & 30 & $0.21 \pm 0.16^{\mathrm{a}}$ & $0.38 \pm 0.009^{\mathrm{cd}}$ \\
\hline & 60 & $0.43 \pm 0.01^{\mathrm{b}}$ & $0.41 \pm 0.006^{\mathrm{b}}$ \\
\hline
\end{tabular}

Means having different small letters $(\mathrm{a}, \mathrm{b}, \mathrm{c} \ldots)$ among treatments for each Column are significantly different $(\mathrm{P}<0.05)$.

Table 12: Effect of different refrigerator storage day on $\mathrm{pH}$ and Water holding capacity on karadi meat treated by different concentration of pomegranate peel and Pomegranate seed extract (Mean $\pm \mathrm{SE}$ ).

\begin{tabular}{|c|c|c|c|}
\hline Treatment & Frozen storage day & $\mathrm{pH}$ value & Water holding capacity \\
\hline \multirow{4}{*}{$\mathrm{C}$} & 0 & $5.06 \pm 0.01^{\mathrm{ab}}$ & $43.93 \pm 0.44^{\mathrm{de}}$ \\
\hline & 30 & $5.20 \pm 0.03^{\text {cde }}$ & $40.70 \pm 0.68^{\text {bcd }}$ \\
\hline & 60 & $5.27 \pm 0.30^{\mathrm{de}}$ & $37.23 \pm 0.48^{\mathrm{a}}$ \\
\hline & 90 & $5.58 \pm 0.006^{\mathrm{a}}$ & $42.89 \pm 0.44^{b}$ \\
\hline \multirow{4}{*}{ PSE } & 0 & $5.17 \pm 0.01^{\mathrm{cd}}$ & $41.87 \pm 0.35^{\mathrm{cd}}$ \\
\hline & 30 & $5.28 \pm 0.03^{\mathrm{de}}$ & $46.66 \pm 1.71^{\mathrm{e}}$ \\
\hline & 60 & $5.22 \pm 0.02^{\text {cde }}$ & $37.90 \pm 0.34^{\mathrm{ab}}$ \\
\hline & 90 & $5.60 \pm 0.04^{\mathrm{a}}$ & $27.73 \pm 1.22^{\mathrm{a}}$ \\
\hline \multirow{4}{*}{ PPE } & 0 & $5.01 \pm 0.02^{\mathrm{a}}$ & $42.06 \pm 0.34^{\mathrm{cd}}$ \\
\hline & 30 & $5.14 \pm 0.03^{\mathrm{bc}}$ & $39.09 \pm 0.35^{\mathrm{abc}}$ \\
\hline & 60 & $5.31 \pm 0.02^{\mathrm{e}}$ & $37.32 \pm 0.42^{\mathrm{a}}$ \\
\hline & 90 & $5.54 \pm 0.01^{\mathrm{a}}$ & $38.52 \pm 1.48^{b}$ \\
\hline
\end{tabular}

Means having different small letters $(\mathrm{a}, \mathrm{b}, \mathrm{c} \ldots)$ among treatments for each Column are significantly different $(\mathrm{P}<0.05)$. 
Table 13: Effect of different concentration of pomegranate peel and Pomegranate seed extract in sensory evaluation scores in LD muscle of Karadi sheep (Mean \pm SE):

\begin{tabular}{rcccccc}
\hline Che. & P.E & Color & $\begin{array}{c}\text { Flavor and } \\
\text { Aroma }\end{array}$ & Tenderness & Juiciness & $\begin{array}{c}\text { Over all } \\
\text { acceptability }\end{array}$ \\
\hline Con. & T1 & $2.80 \pm 0.20^{\mathrm{a}}$ & $2.60 \pm 0.24^{\mathrm{a}}$ & $3.00 \pm 0.31^{\mathrm{ab}}$ & $3.00 \pm 0.20^{\mathrm{ab}}$ & $2.40 \pm 0.24^{\mathrm{a}}$ \\
\hline & T2 & $3.20 \pm 0.37^{\mathrm{a}}$ & $3.00 \pm 0.44^{\mathrm{ab}}$ & $3.80 \pm 0.37^{\mathrm{b}}$ & $2.80 \pm 0.37^{\mathrm{ab}}$ & $3.20 \pm 0.37^{\mathrm{ab}}$ \\
\cline { 2 - 7 } PSE & T3 & $3.80 \pm 0.48^{\mathrm{a}}$ & $3.40 \pm 0.24^{\mathrm{ab}}$ & $3.80 \pm 0.48^{\mathrm{b}}$ & $2.80 \pm 0.20^{\mathrm{ab}}$ & $3.80 \pm 0.48^{\mathrm{b}}$ \\
\cline { 2 - 7 } & T4 & $3.40 \pm 0.40^{\mathrm{a}}$ & $4.00 \pm 0.44^{\mathrm{b}}$ & $4.00 \pm 0.31^{\mathrm{b}}$ & $3.40 \pm 0.24^{\mathrm{b}}$ & $3.40 \pm 0.40^{\mathrm{ab}}$ \\
\cline { 2 - 7 } & T5 & $3.60 \pm 0.24^{\mathrm{a}}$ & $3.20 \pm 0.20^{\mathrm{ab}}$ & $3.80 \pm 0.20^{\mathrm{b}}$ & $3.00 \pm 0.54^{\mathrm{ab}}$ & $3.60 \pm 0.24^{\mathrm{b}}$ \\
\hline & T6 & $3.60 \pm 0.40^{\mathrm{a}}$ & $3.60 \pm 0.24^{\mathrm{ab}}$ & $3.40 \pm 0.4^{\mathrm{b}}$ & $3.20 \pm 0.20^{\mathrm{ab}}$ & $3.40 \pm 0.40^{\mathrm{ab}}$ \\
\cline { 2 - 7 } PPE & T7 & $2.80 \pm 0.37^{\mathrm{a}}$ & $2.60 \pm 0.40^{\mathrm{a}}$ & $3.00 \pm 0.31^{\mathrm{ab}}$ & $2.40 \pm 0.24^{\mathrm{ab}}$ & $2.80 \pm 0.37^{\mathrm{ab}}$ \\
\cline { 2 - 7 } & T8 & $3.00 \pm 0.31^{\mathrm{a}}$ & $3.20 \pm 0.58^{\mathrm{ab}}$ & $3.20 \pm 0.37^{\mathrm{b}}$ & $2.40 \pm 0.24^{\mathrm{ab}}$ & $3.00 \pm 0.31^{\mathrm{ab}}$ \\
\cline { 2 - 6 } & T9 & $2.40 \pm 0.24^{\mathrm{a}}$ & $3.60 \pm 0.24^{\mathrm{ab}}$ & $2.00 \pm 0.00^{\mathrm{a}}$ & $2.00 \pm 0.40^{\mathrm{a}}$ & $2.80 \pm 0.20^{\mathrm{ab}}$ \\
\hline
\end{tabular}

Means having different small letters $(\mathrm{a}, \mathrm{b}, \mathrm{c}, \ldots$.$) among treatments for each Column are significantly different (\mathrm{P}<0.05)$.

\section{DISCUSSION}

In this study we found that PSE showed decrease of moisture percentage as compared with controls T1 (75.59\%). Also decreases of moisture percentage were observed for all treatment except T1 at (30) days frozen $(81.74 \%)$ which record highest moisture percentage as compared with control and other treatments (table 2). PPE at T7 recorded lower Moisture content as compared with other treatments during (90) days frozen. This finding may be due to opposite linkage between the moisture and other compounds present in meat sample treated by pomegranate peel or seed extraction (Tahir, 1983 and Guo et al., 2003). The decrease in moisture content were recorded for all treatments during storage period processed was confirmed by (Kheder, 2013) after using different Olive leave extraction on karady sheep meat during frozen storage. Other research conducted that in disparity to the emulsion, moisture content in the product with guava powder $(1 \%)$ was significantly lowers $(\mathrm{P}<0.05)$ than control. This could be due the loss of water/ moisture, temporarily bound by the guava powder (Arun and Rajkumar. 2013).

PSE and PPE showed rise of protein content Table (3). and T2 during (90) days frozen recorded the higher protein content (19.00\%) and T2 during (30) days frozen was the lowest protein content (14.18\%). These results are probably due to the phenolic components in the plants extracts which improve proteins and meat moisture and prevented water loss (Romans and Ziegler, 1977; Saleh, 2007). The result were confirmed by (Baker I. A. 2012), when reported that protein content increased significantly $(\mathrm{P}<0.01)$ with increase of storage of meat sample treated by Ginger extract and Rosemary extract. On the other hand, (Kheder 2013) showed that significant differences appeared in protein content among meat sample treated by Olive leave extraction during frozen storage.

Significant differences $(\mathrm{P}<0.05)$ observed among the means of Fat (table 4) in meat sample after treated by PSE and PPE, Gradually Fat content increased in all treatments as control with control. (Taban 2015) founded that Treatments $\mathrm{T} 2$ and $\mathrm{T} 4$ shows decrease in each protein and fat comparing with control. Also Significant differences $(\mathrm{P}<0.05)$ of Fat content reported by (Kheder 2013) in meat sample treated with olive leave extraction during frozen storage at $18^{\circ} \mathrm{C}$

Rise of Ash content were observed in all sample treated by PSE and PPE when compared with control. Arvanitoyannis et al. (2000), confirm that significant increase in Ash with increase of storage period due to loss of moisture which in turn made an increase in the total solid content.

The result in table (6) show that there is a significant difference $(\mathrm{P}<0.05)$ among the means of TBA value in karady sheep meat treated by different concentration of PSE and PPE, The results of present study may be related to the antioxidant characteristics of GE (Ginger extraction) (Brunton et al., 2000), which prevented lipid oxidation in the phospholipids rich membranes of meat (Lee et al., 1986; Kim and Lee, 1995; Mendiratta et al., 2000).

PSE and PPE recorded gradually increase in FFA content, the increase in FFA (lipolysis) is a result of the enzymatic hydrolyses of esterifies lipids (Hwang and Regenstein, 1993). Increase in FFA is in agreement with those reported by other investigators (Ucak et al., 2011; Abu-almaaly, 2011). In spite of that, Ucak et al. (2011) noticed considerable differences $(\mathrm{p}<0.01)$ in FFA between the control and rosemary extraction treated groups. 
Generally decrease of $\mathrm{pH}$ value was observed in all treatment after treated by different percentage of PSE and PPE at some storage day This result may be due to the presence of some acids like Ellagic acid and its derivatives (Ellagitannis, Punicalagin, Punicalin) in pomegranate peel extracts which may decrease the pH of meat (Tahir, 1983 and Guo et al., 2003). The $\mathrm{pH}$ values of raw ground pork meat decreased from 5.88 to 5.61 over storage period (Qin and Zhang 2013).

Pomegranate Peal extraction showed significantly effect in WHC which decreased the WHC value compared with PSE (Table 9) The present results are similar to the findings of previous reports which showed stabilizing effect on thawing and cooking loss and other meat quality with increase ginger extract concentration (Naveena and Mendiratta, 2004; AlTemimi and Abu-Almaaly, 2011). The meat samples treated with olive leaves extract in low concentration (2\%) had lower WHC which might be because of protein lose their buffering capacity (Offer and Trinick, 1983).

The moisture losses happen during later storage periods due to myofibrillar distortion undergone by the meat in the freezer that led to the poor water retention ability of the meat. (Kandeepan and Biswas, 2007b). Similar result was found by (Hama et al., 2018) when indicated that moisture content decreased significantly $(\mathrm{P}<0.01)$ with increasing storage for all meat sample treated with pomegranate peel extract. Similar results were found by (Azad and Akter, 2005) and Kandeepan and Biswas (2007a) and Al-penjueni (2008). generally protein content Increased with increase of frozen period. The result was confirmed by (Ageena, 2001) and (Al- Dhaheri, 2012) which reported higher protein content of calve meat and minced beef during frozen storage as a period of storage increased. In present study gradually increase of Fat content observed with gradually increase of frozen storage period value was gradually increased during the increase of storage period (Baker, 2012). Similar result was found by (Kheder, 2013) fat content in karadi sheep meat was increased during frozen storage for $(0,30$, and 60$)$. On the other hands, Ash content gradually increased as the period of storage frozen increased same result were founded by (Kheder, 2013), Ageena (2001) and Al-Dhaheri (2012) whom found that Ash content gradually increased as the period of storage frozen increased.

The TBA value decreased significantly in all treatments due to Increase of frozen storage time The results revealed that the meat which treated with Pomegranate Peel extracts showed a preservation effect on meat by inhibiting lipid oxidation due to its antioxidants contents like flavonoids, ellagic acid, catechins and Gallic (Li et al., 2006, Zahin et al., 2010 and Devatkal et al., 2010). TBA value reduced in meat and meat process during frozen storage (Wojciak et al., 2011). After 4 weeks of chilled storage of meat treated with mint leaf extract the TBA value decreased (Kannat et al., 2007).

Increases of FFA content observed with increase of frozen storage days $(0,30,60$ and 90) Present study showed that FFA content increase with increase of frozen period, lower FFA recorded in control at (0) time was $(0.21 \%)$ and the higher FFA content was $(0.41 \%)$ recorded by meat sample treated with PPE storage for 90 days frozen. Mahmmod (2014) reported that when compared FFA values of same treatment in different periods, results showed that FFA values increase as storage period increase.

The $\mathrm{pH}$ value affected by different frozen storage days, gradually increase of $\mathrm{pH}$ value recorded with increase of frozen storage days Hama et al. (2018), reported that $\mathrm{pH}$ value of karadi ram meat increased with increase of refrigerated storage period, there were significant differences $(\mathrm{P}<0.01)$ between storage periods for all treatments. Thus the result revealed that $\mathrm{pH}$ values increased with progress in storage period similar result was indicated by Jayesh and Venkataramanujam (2000) and Kandeepan and Biswas (2007a). Increase in $\mathrm{pH}$ significantly with prolonged freezer storage may be attributed to the fact that meat undergoes autolysis resulting in a decrease in extract release factor and water holding capacity (Strange et al., 1977). Reduction of WHC percentage was obtained in the present study as a result of different storage period Table (12). Similar result was found by Kheder (2013) when indicated that all karadi sheep meat treated with olive leave extract showed a gradually decrease in WHC as storage time was progressed. Result showed that WHC significantly $(\mathrm{P}<0.01)$ decreased as storage time increased Hama et al. (2018).

The karadi sheep meat exhibited higher $(\mathrm{P}<0.05)$ Flavor and aroma, Tenderness and Juiciness in meat treated with PSE at $(0.9 \%)$. and recorded higher Color and over all acceptability at T3 (PSE 0.6\%) compared withT1. These results may be due to that pomegranate extracts contain flavonoid compounds and catechins, which play effective role in myoglobin reduction and maintaining the longest storage period, thus providing meat color protection through delay the met - myoglobin formation (Naveena et al., 2008b). Similar result was found with (Al-Rubeii et al., 2009; Sallam et al., 2010; Zochowska-Kujawska et al., 2013) when used GE (Ginger extraction) to improve the meat quality and the result was improvement in tenderness and juiciness after GE (Ginger extraction) treatment that improvement may be due to proteolytic activity of ginger extract, enhancing meat ability to bind water and decreasing exudative liquid loss during thawing. 


\section{CONCLUSION}

The study demonstrated the antioxidant effect of pomegranate peel and pomegranate seed extract on karady sheep meat during $(0,30,60$ and 90) days frozen the result confirmed that

1- Chemical and physical analysis indicated that PSE and PPE had high antioxidant activity and retarded the lipid oxidation, which is very important for human health benefit.

2- Improvement of Flavor and aroma, Tenderness, Juiciness, Color and Overall acceptability were observed after treated the meat sample with different concentration of PSE and PPE.

3- Nutritional value of karadi sheep meat was increased after adding PSE and PPE to meat samples which lead to decrease of Moisture content and as a result caused a relative increase in Protein, Fat and FFA.

4- There were significant differences between the sample of meat for chemical and physical treats of meat during different frozen storage time.

\section{REFERENCES}

Abu-almaaly, R.A. (2011): "The effect of ginger (Zingiber Officinale) on the quality characteristics of fresh and frozen local beef burger" M.Sc. Thesis, College of Education for women, University of Baghdad.

Ageena, S.J.M. (2001): Effect of Frozen storage time and packaged factor of the calve meat on its expire for consumption with chemical sensory and bacterial indicators. M.S. Thesis, Food Science and Biotechnology. College of Agriculture, Univ. of Baghdad.

Al-Penjueni, A.B.M. (2008): Effect of aging time and freezing storage on some qualitative, characteristic of karadi ewe meat from different ages. $\mathrm{Ph}$. D. Thesis, University of Sulimania.

Al-Dhaheri, S.KH.M. (2012): Studding the effect of addition of origaniom majoranol.,(marjoram) and their extracts on some quality characteristics of minced beef meat during frozen storage. M.S. Thesis, Animal Resources. College of Agriculture, Univ.of Baghdad.

Al-Quran. Surah Al-Rehman. Chapter 27, Surah no. 55, Verse No.68.

Al-Rubeii, A.; Al-Kaisey, M.S.M.T. and Khadom, M.J. (2009): Comparative of the antioxidant potential of natural plants with synthetic antioxidants during cold storage of ground beef meat. Alex Journal of Food Science and Technology, 6: 1-16.

Al-Temimi, S.S. and Abu-Almaaly, R.A. (2011): The Effects of Ginger (Zingibarofficinale) on physical properties and the Sensory Evaluation of beef burger. Iraq Journal for Market Research and Consumer Protection, 3: 31-52.

AOAC (Association of official Analytical Chemists) (2000): Official Methods of analysis. $17^{\text {th }}$ t dn., Washington, USA.

Arun K. Verma and Rajkumar, V. (2013): Guava (Psidiumguajava L.) Powder as an Antioxidant Dietary Fiber in Sheep Meat Nuggets. AsianAustralasian Journal of Animal Sciences.

Arvanitoyannis, I.S.; Bloukas, J.G.; Pappa I. and Psomiadou, E. (2000): Multivariate data analysis of Cavourma- a Greek cooked meat product. Meat Sci., 54 (1): 71-75.

Azad, M.A.K. and Akter, S. (2005): Influence of freezing time on the quality of beef. J. Animal and Veterinary Advances. 4:424-426.

Baker, I.A. (2012): Effect of some plant extracts on the changes in chemical and microbial quality of karadisheep meat during storage.

Braga, L.C.; Leite, A.A. and Xavier, K.G. (2005): Synergic interaction between pomegranate extract and antibiotics against Staphylococcus aureus. Can. J. Microbiol., 51: 541-547.

Brunton, N.P.; Cronin, D.A.; Monahan, F.J. and Durcan, R. (2000): A comparison of solid phase microextraction (SPME) fibers for measurement of hexanal and pent anal in cooked turkey. Food Chemistry, 68: 339-345.

Burt, S. (2004): Essential oils: Their antibacterial properties and potential applications in foodsA review. Int. J. Food Microbiol, 94: 223-253.

Devatkal, S.K.; Narsaiah, K. and Borah, A. (2010): Anti-oxidant effect of extracts of kin now rind, pomegranate rind and seed powders in cooked goat meat patties. Meat Science. 85: 155-159.

Duncan, D.B. (1955): Multiple Range and Multiple F- Test. Biometrics, 11, 1-5.

Egan, H.; Kirk, S. and Sawyer, R. (1981): Fresh food: Pearson's Chemical Analysis of food, $8^{\text {thed, }}$ London Group L+D, New York.

Guo (2003): Antioxidant activities of peel, pulp and seed fractions of common fruits as determined by FRAP assay. Nutrition Research 23(12): 1719-1726.

Guo (2003): Evaluation of antioxidant properties of pomegranate peel extract in comparison with pomegranate pulp extract. Journal of Food Chemistry, 96: 254-260.

Hama, A.A. (2018): Effect of Pomegranate Peel extract on some physical, chemical traits and sensory evaluation of Karadi ram meat during refrigerate storage. Euphrates Journal of Agriculture Science- 10 (3): 131-140.

Hwang, K.T. and Regenstein, J.M. (1993): Characteristics of mackerel mince lipid hydrolysis. J. Food Sci., 58: 79-83.

Ibrahim, H.M.; Abou-Arab, A.A. and Abu Salem, F.M. (2011): Addition of some natural plant extracts and their effects on lamp patties quality. J. Food Tech., 8: 134-142. 
Jayesh, V. and Venkatarmanujam, V. (2000): Effect of chilling and freezing on physic chemical quality of mutton. Indian Vet J., 79: 743-745.

Jeune, M.A.; Kumi-Diaka, J. and Brown, J. (2005): Anticancer activities of pomegranate extracts and genistein in human breast cancer cells. J. Med. Food, 8: 469-475.

Kandeepan, G. and Biswas, S. (2007a): Effect of Low Temperature Preservation on Quality and Shelf Life of Buffalo Meat. American Journal of Food Technology 2(3). March 2007.

Kandeepan, G. and Biswas, S. (2007b): Effect of domestic refrigeration on keeping quality of buffalo meat. J. Food Tech., 5: 29-35.

Kannat, S.R.; Chander, R. and Sharma, A. (2007): Antioxidant potential of mint (MenthaspicataL.) in radiation-processed lamb meat. Food Chemistry, 100, 451-458.

Kheder, R.H. (2013): Effect of different concentrations of olive leaves extraction on quality characteristics of karadi sheep meat during frozen storage, College of Agriculture, University of Baghdad. Iraq.

Kim, K.J. and Lee, Y.B. (1995): Effect of ginger rhizome extract on tenderness and shelf life of pre-cooked lean beef. Asian Australian Journal of Animal Science, 8: 343-346.

Lawrie, R.A. (2002): The eating quality of meat. In: Meat Science, $5^{\text {th }}$ Edition, pergamon Press. 173-176, 184-188.

Lee, Y.B.; Sehnert, D.J. and Ashmore, C.R. (1986): Antioxidant property in ginger rhizome and its applications to meat products. Journal of Food Science, 51: 20-23.

Li, Y.; Guo, C.; Yang, J.J.; Wei, J.; Xu J. and Cheng. $S$. (2006): Evaluation of antioxidant properties of pomegranate peel extract in comparison with pomegranate pulp extract. Food Chemistry. 96: 254-260.

Mahmmod Ayad, B. (2014): study the effects of olive leaf extract on physio-chemical and sensory traits of mutton meat at low temperature. Department of animal production, faculty of agricultural sciences, university of sulaimani. Assiut vet. med. j. vol. 60 no. 143 October 2014.

Mendiratta, S.K.; Anjaneyulu, A.S.R.; Lakshmanan, V.; Naveena, B.M. and Bisht, G.S. (2000): Tenderizing and antioxidant effect of ginger extract on sheep meat. Journal of Food Science and Technology, 37: 565-570.

Murphy, M.A. and Zerby, H.N. (2004): Pre-rigor infusion of lamp with sodium chloride, phosphate, and dextrose solutions to improve tenderness, Meat Sci. 66: 343-349.

Namiki, M. (1990): Crit. Rev. Food Sci. and Nutrition, 273-279.

Naveena, B.M. and Mendiratta, S.K. (2004): The tenderization of buffalo meat using ginger extract. Journal of Muscle Foods, 15: 235-244.
Naveena, B.M.; Sen, A.R.; Kingsly, R.P.; Singh, D.B. and Kondaiah, N. (2008b): Antioxidant activity of pomegranate rind powder extract in cooked chicken patties. Int. J. Food Sci. Tech., 43(10): 1807-1812.

Offer, G. and Trinick, J. (1983): On the mechanism of water holding in meat: the swelling and shrinking of myofibrils. Meat Sci., 8: 245-251.

Ozgen, M.; Durgac, C.; Serce, S. and Kaya, C. (2008): Chemical and antioxidant properties of pomegranate cultivars grown in Mediterranean region of Turkey. Food Chem., 111: 703-706.

Qin and Zhang (2013): Antioxidant effect of pomegranate rind powder extract, pomegranate juice, and pomegranate seed powder extract as antioxidants in raw ground pork meat. In Food Science and biotechnology. 22 (4).

Romans, J.R. and Ziegler, P.T. (1977): The Meat We Eat. The Interstate Printers and Publishers, Inc., U.S.A.

Sallam, K.; Ishioroshi, M. and Samejima, K. (2010): Antioxidant and antimicrobial effects of ginger in chicken sausage. Meat Science, 37: 849855.

Saleh (2007): Malaysian Governmental Accounting: National Context and User Orientation, International Review of Business Research Papers, Vol.3 No.2 June, pp.376-384.

Shah, M.A.; Bosco, S.J.D. and Mir, S.A. and Plant extracts as natural antioxidants in meat and meat products, Meat Science (2014): doi: 10.1016/j.meatsci.2014.03.020

Strange, E.D.; Benedict, R.C.; Smith, J.I. and Swift, C.E. (1977): Evaluation of Rapid tests for monitoring alteration in meat quality during storage J. Food Prot., pp843- 847.

Taban N.M.AL-Daoudi (2015): Effect of ginger extracts treatment and refrigeration storage on some chemical, sensory and bacteriological characteristics of karadi lambs meat.

Tahir, M.A. (1983): Principles of meat science. College of Agriculture. Basra University. Iraq (in Arabic).

Tzulker, R., Glazer, I.; Bar-Ilan, I.; Holland, D.; Aviram, M. and Amir, R. (2007): Antioxidant activity, polyphenol content and related compounds indifferent fruit juices and homogenates prepared from29 different pomegranate accessions. J. Agric. Food Chem., 55: 9559-9570.

Ucak, I.; Ozgul, Y. and Durmus, M. (2011): "The effects of rosemary extract combination with vacuum packing on the quality changes of atlantic mackerel fish burgers", International Journal of Food science and Technology, 46: 1157-1163.

Wardlaw, F.B.; Maccaskill, L.H. and action, J.C. (1973): Effect of post mortem muscle changes in poultry meat loaf properties. J. food Sci. 38: 421- 424. 
Williamson (2005): Red meat in the diet. British Nutrition Foundation, London, UK. Nutrition Bulletin, 30, 323-355.

Witte, V.C., Krause, G. and Bailey, M.E. (1970): "A new extraction method for determining 2thiobarbituric acid values of pork and beef during storage", Journal of Food Science, 35: 582-585.

Wojciak, K.M.; Dolatowski, Z.J. and Okon, A. (2011): The effect of water plant extracts addition on the oxidative stability of meat products. Acta
Scientiarum Polonium, Technologia Alimentaria, 10, 175-188.

Zahin, M.; Aqil, F. and Ahmad, I. (2010): Broad spectrum ant mutagenic activity of antioxidant active fraction of PUNICA GRANATUML. Peel extracts. Mutat. Res. 703: 99-107.

Zochowska-Kujawska, J.; Lachowicz, K.; Sobczak, M.; Nedzarek, A. and Torz, A. (2013): Effects of natural plant tenderizers on proteolysis and texture of dry sausages produced with wild boar meat addition.African Journal of Biotechnology, 12: 5670-5677.

\title{
تاثير المستخلص المائي لقشور وبذور الرمان على بعض الصفات الكيميائية والفيزيائية والحسية للحم الضأن

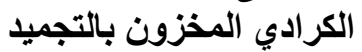

\author{
آلان توفيق غريب الدباغ ، اياد بكر محصود.
}

E-mail: alan_dabagh@yahoo.com Assiut University web-site: www.aun.edu.eg

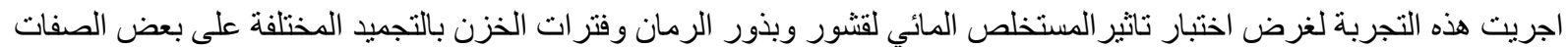

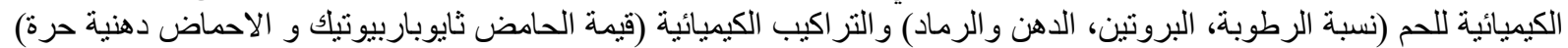

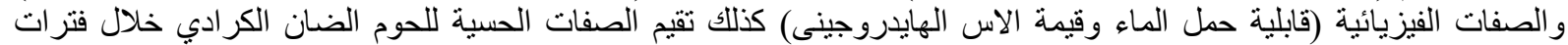

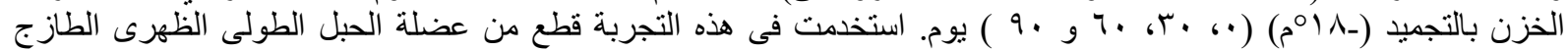

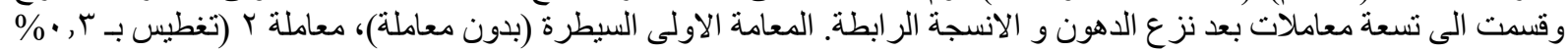

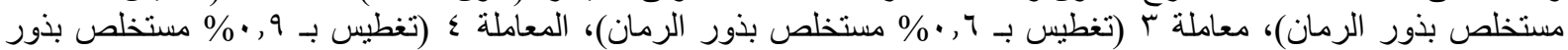

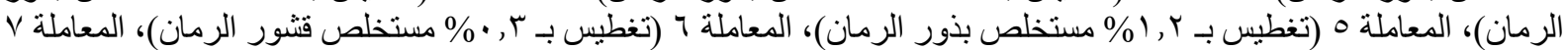

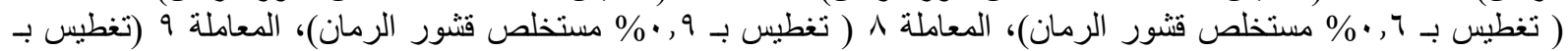

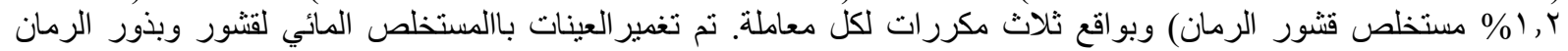

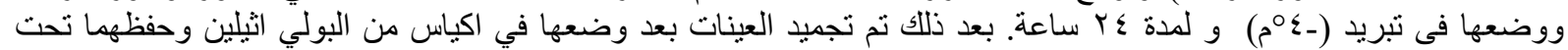

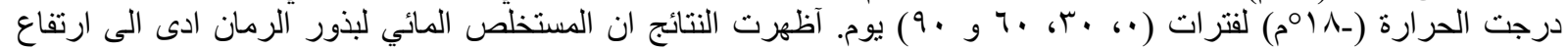

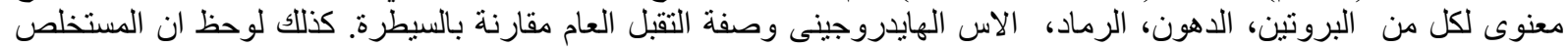

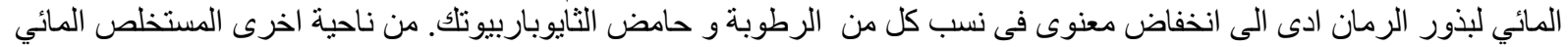

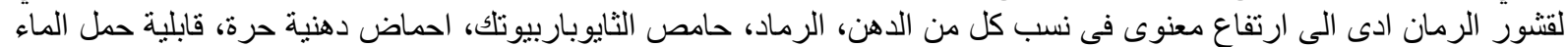

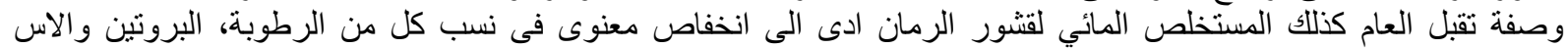

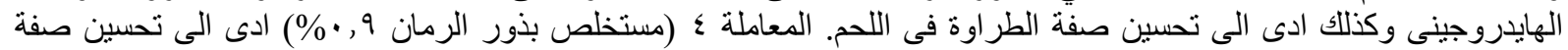

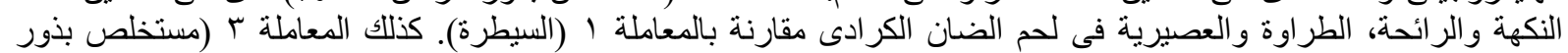

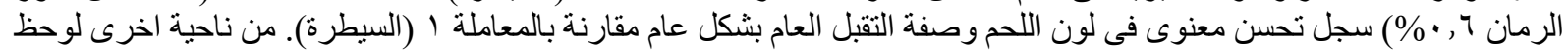

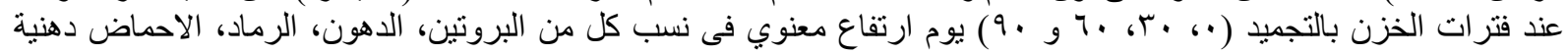

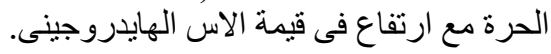

